\title{
Tropicality, the unruly Atlantic and social utopias: the French explorer Henri Coudreau (1859-1899)
}

\author{
Federico Ferretti \\ School of Geography, University College Dublin, Belfield, Dublin, Ireland
}

This paper addresses the works of Henri Coudreau, a little-known French explorer of Guiana and Amazonia who was later forgotten by the 'heroic' histories of exploration because of his unruliness and nonconformist attitudes. Drawing on the literature of postcolonialism and tropicality as well as on recent studies of anti-colonialist geographies, I address for the first time Coudreau's geography from the perspective of anarchist and critical thinking. My main argument is that Coudreau's work is a further example of the complexity and heterogeneity of the European intellectual field during the imperial age. Despite having come of age intellectually among all the European racist and ethnocentric prejudices of his day, Coudreau developed a different outlook thanks to two factors, viz., his personal experience in living for years with the indigenous communities of Amazonia, and his exposure to anarchist anti-colonialist ideas through his collaboration with Elisée Reclus. Coudreau's tropical utopia of an independent Amazonia, and his endorsement of the stateless nature of local communities, ran counter to French imperial politics, occasioning Coudreau's dismissal from the French administration and his professional exile in Brazil at the time of the Franco-Brazilian border dispute (1897-1900).

Keywords: Coudreau, tropicality, anarchism, explorations, postcolonial studies

\section{Introduction}

In the last thirty years or so, critical geographers have increasingly questioned the colonial legacy of their discipline, engaging with postcolonial and subaltern scholarship (Clayton, 2011; Jazeel, 2014; Nash, 2002; Sidaway, 2000) and drawing inspiration from early critiques of Eurocentrism in geography (Blaut, 1993) and mapping (Harley, 2001). Explorers have been often defined as the vanguards of empire and imperial mapping (Burnett, 2000; Pratt, 1992; Akermann, 2008), and many of them are analysed from the conceptual framework of the invention of 'tropicality', which

F. Ferretti, 2017: "Tropicality, the unruly Atlantic and social utopias: the French explorer Henri Coudreau (1859-1899)", Singapore Journal of Tropical Geography 38, 3, early view: http://onlinelibrary.wiley.com/doi/10.1111/sjtg.12209/full 
implies 'the identification of the Northern temperate regions as the normal... the tropics as altogether other — climatically, geographically and morally — became part of an enduring imaginative geography' (Driver \& Yeoh, 2000: 1). In colonial ages, the world between the two tropics was seen as a specific environment where orientalist dreams of exploration and conquest were projected (Driver, 2004; Driver \& Martins, 2005; Staszak, 2003), and spaces allegedly rich in exploitable resources long maintained a powerful attraction for Western imaginaries (Power \& Sidaway, 2004; Puyo, 2001), in spite of the opposite negative myths on the 'torrid zone' (Safier, 2014).

Nevertheless, research has demonstrated that explorers' endeavours were inserted in the wider context of the circulation of print (imperial) cultures and that complex relationships existed between fieldwork, the scientific societies and the final publication of explorations (Driver, 2001; Ogborn, 2007; Keighren et al., 2015). French scholarship has shown that the travels of French explorers in Africa and the Pacific islands were far from automatically corresponding to a future French occupation (Blais, 2005; Surun, 2007). Recent historiography demands critical work on early European explorers in order 'to interrogate their cultural and political purposes and reveal the realities in the field that complicated and countered some purposes' (Kennedy, 2014: 7) and geographical scholarship is more and more concerned with anti-colonialist, antiracist and internationalist issues in the field of European science in imperial ages (Ferretti, 2013; Featherstone, 2012; Bressey, 2013).

This paper addresses the figure of the nonconformist and unruly French explorer Henri Coudreau (1859-1899), who travelled for almost twenty years in Amazonia and the Guiana, publishing twelve books and more than thirty papers. My research draws on an integral survey of these texts, and of the few archive documents I mention below, which I interrogated in order to better understand Coudreau's political ideas and his views of the indigenous communities he visited. I also used these sources as biographical references, considering their autobiographical character. Thus, in order to better understand his contexts, I considered not only discursive analysis but also biographical references, as I tried to compare the texts with concrete practices Coudreau deployed. In French writing, Coudreau's name is generally linked to two main facts, i.e., the proclamation of the Republic of Counani in 1886 and the 1897-1900 Franco-Brazilian border

F. Ferretti, 2017: "Tropicality, the unruly Atlantic and social utopias: the French explorer Henri Coudreau (1859-1899)", Singapore Journal of Tropical Geography 38, 3, early view: http://onlinelibrary.wiley.com/doi/10.1111/sjtg.12209/full 
dispute upon Guiana, resolved by the arbitration of the Swiss government in favor of Brazil. In both cases he was unpopular in colonial milieus in Paris and Cayenne, as his autonomous political and scientific agenda was considered an irregular activity which interfered abusively with the interests of the French state (Puyo, 2012). Coudreau, who had started his career in the context of official imperial missions for the French government, was increasingly marginalized and finally dismissed for his indiscipline. He ended his career as a 'freelance' explorer appointed by the governor of the Brazilian state of Pará (Ferretti, 2015).

As the aforementioned studies on the Franco-Brazilian border dispute show, the South American area was a marginal one for French politics and public opinion, which were concentrated on African imperialism and assumed negative stereotypes on Amazonian tropicality as the 'Green Hell', a view that Coudreau tried to challenge. As stated by his biographers Sébastien Benoit and Max Mouchet, Coudreau's detestation by French colonial milieus was echoed by French historiography, who has traditionally considered him an unreliable and 'inaccurate' source, a 'fool', a 'liar' (Hurault, 1973), or, in the best light, according to Benoit, the product of the 'contradictions' of his time (Benoit, 2000). My challenge to these Francocentric points of view lies in my attempt to take seriously for the first time Coudreau's geographical work. My main argument is that Coudreau, when he began his explorations at the age of twenty-three, was immersed in all kinds of eurocentric, ethnocentric and racist stereotypes, and that he gradually lost most of them thanks to two main experiences, i.e., his living for years among Amerindian communities in the tropical forest (sharing their food, nakedness and social customs), and his acquaintance, during his shorts stays in Europe, with anarchist anti-colonialists like Elisée Reclus (1830-1905), the French geographer and protagonist of a radical questioning of colonialism, racism and Eurocentrism in the Age of Empire (Ferretti, 2013).

Drawing on the recent historiographic contributions collected in the book Reinterpreting Exploration edited by Dane Kennedy, I argue that Coudreau's experience of living with Amazonian tribes contributes to a better understanding of several points on which the recent historiography on explorations focuses. It is the case of the contact zones between 'explorers' and 'explored', theatre of 'quotidian encounters with other peoples' (Kennedy, 2014: 8), which enable scholarship to 'trace the sources and discern the patterns of cultural encounters and exchanges' (Kennedy, 2014: 12). If

F. Ferretti, 2017: "Tropicality, the unruly Atlantic and social utopias: the French explorer Henri Coudreau (1859-1899)", Singapore Journal of Tropical Geography 38, 3, early view: http://onlinelibrary.wiley.com/doi/10.1111/sjtg.12209/full 
Coudreau was a classic example of the link between exploration and science, his case corroborates present-day critiques to interpretative models assuming the spreading of scientific knowledge from a centre to a periphery, which is what Michael F. Robinson defines as 'new views of scientific exploration as a collaborative and reciprocal process between cultures, specifically between explorers and local inhabitants' (Robinson, 2014: 32). Coudreau's travels, which were more akin to what Harry Liebersohn describes as the 'individual['s] encounter' (Liebersohn, 2014: 39) rather than the organized exploration, are also an example of the ambivalences of the intellectual tradition to which he belonged, namely the Enlightenment concept of the Republic of Letters which, according to Philip J. Stern, 'provided the foundation for modern empire and the sine qua non of the Enlightenment critique of colonization, expansion and slavery. In fact, the intersections between exploration and Enlightenment highlighted any number of debates, tensions and complexities in each' (Stern, 2014: 62). As an explorer who was also considered to be a philosophe [Enlightenment philosopher] according to Stern's model, Coudreau is interesting to present-day scholarship because his case, among others, allows us to consider dissidence in imperial ages, often overlooked by essentializing narratives on European science and Empire. Furthermore, Coudreau is an example of the impact of Reclus's works outside of the strictly defined anarchist field, as Coudreau, a complex and contradictory figure, never assumed any political label.

Indeed, Coudreau's writings are often confusing and contradictory, and it is not there that one might seek a theoretical solution of the contradiction between the Enlightenment's universal claims for human rights and European colonialism (Chakrabarty, 2000). What I argue is first that Coudreau's personal tropical utopia can only been understood in the context of some libertarian socialism, leading him to champion an independent Amazonia resulting from the miscegenation between Indians and European proletarians migrating spontaneously out of the colonial state's control. This might be considered as an early expression of the concept now called 'militant tropicality' by Clayton (2013), though it does not present the same insurgent character of the tropical guerrillas in the twentieth century: nevertheless, it is an example of link between a tropical environment and a socialistic political project. The biography of a maverick and unruly explorer like Coudreau can be understood in the context of rebel and subaltern Atlantic circulation (Linebaugh \& Rediker, 2000; Featherstone, 2008), and more specifically in the cosmopolitan

F. Ferretti, 2017: "Tropicality, the unruly Atlantic and social utopias: the French explorer Henri Coudreau (1859-1899)", Singapore Journal of Tropical Geography 38, 3, early view: http://onlinelibrary.wiley.com/doi/10.1111/sjtg.12209/full 
'Caribbean circulation' addressed by the Brazilian historian Carlo Romani, referring to the 'stateless people' who occupied informally the contested territory between French Guiana and Brazil (Romani, 2013). Coudreau's work also provides an early example of non-statist geographies, inserted in regional frameworks different from the statist and institutional ones, addressed by contemporary scholarship on anarchist and post-statist geographies (Ince \& Barrera, 2016; Springer, 2012). This can be considered as a case in the construction of subaltern geographies and geopolitics, which Tariq Jazeel considers not only as the space occupied by subaltern groups, but also as a spatiality 'occluded by the hegemonic conceptualizations of space that pervade our discipline' (Jazeel, 2014: 88) belonging to 'ways of thinking spatially that may be considered lower ranking in the context of disciplinary geography's Eurocentric hegemony' (Jazeel, 2014: 95).

Finally, Coudreau's work contributes to present-day debates on postcolonial and subaltern geographies. It is especially the case with the concept of 'planetary indigeneity' developed by James Sidaway, Chih Woon and Jane Jacobs, who argued that, though the concept of indigeneity was elaborated in imperial contexts and implied that 'indigenous people were labelled savages, a categorization that justified displacement, exclusion and even massacre' (Sidaway et al., 2014: 8), it is worth considering that today 'others, including indigenous people themselves, counter that the concept is meaningful and, because now enshrined in certain instruments of recognition, necessary' (Sidaway et al., 2014: 9). Coudreau can enrich this category in two ways: first, because he provided original proposals for fraternization and miscegenation between Amazonian indigenous and European proletarians, problematizing the contemporary notion of 'settler contexts'; second, because his praise for the possibility of a different way of life suggested by Amazonian tribes anticipated present-day 'new attention to indigenous ways of being [as] a resource of hope for a new planetary consciousness' (Sidaways et al., 2014; 10). In the case of Coudreau, this did not apply to present-day anxieties like climate change but to anxieties present during his time which were poverty and hunger suffered by the working class.

In the first part of my paper, I examine the impact on Coudreau of Amerindian cultures and their environment, which led him to think that he would never be able to reintegrate into 'civilization'; in the second part, I analyse Coudreau's tropical utopia and his idea of miscegenation and a 'cosmopolitan Amazonia'; in the third part I go over Coudreau's attitude towards the Franco-

F. Ferretti, 2017: "Tropicality, the unruly Atlantic and social utopias: the French explorer Henri Coudreau (1859-1899)", Singapore Journal of Tropical Geography 38, 3, early view: http://onlinelibrary.wiley.com/doi/10.1111/sjtg.12209/full 
Brazilian border dispute and his final move to Brazil, which French colonial milieus viewed as treason.

\section{'Safer than the City': the tropical forest and the Amerindians}

Before Coudreau (and after Humboldt), the two most famous European explorers who travelled between Guiana and Northern Amazonia related their encounters with Amerindians without apparently questioning either their own ethnocentrism or the environmental determinism addressing tropical humankind as 'naturally' inferior. The first of these figures, Robert Hermann Schomburgk (1805-1864), was analysed by Graham Burnett, who looked into the 'invention' of the territory of British Guiana through imperial surveys. According to Burnett, the reconstruction of these expeditions showed that 'Amerindians were by no means passive or childlike witnesses of geographical exploration in the interior of British Guiana. Close attention to the written production of those expeditions (and its omissions) reveals that the depiction of the Amerindian as fragile and dependent on European agency misrepresented the relationship that emerged' (Burnett, 2002: 33). Thus, local tribes had clear agency in shaping explorers' itineraries, whether in collaboration or opposition, even if Europeans refused to grant them this subjectivity. 'Examining how Hilhouse and Schomburgk represented the Amerindian has demonstrated how expedition writing did a certain kind of colonial work, narrowly shaping the histories and characters of indigenous people ... This work involved minimizing Amerindian knowledge and power in an effort to reflect the superiority of the European' (Burnett, 2002: 33). On the other hand, 'reconstructing the role of the Amerindian in the practice of expedition, in the acquisition of geographical knowledge... not only points to patterns in the work of the explorer/authors who worked in the colonial context in the mid-nineteenth century, it also gives us a better understanding of the relationship between science and imperialism in the period' (Burnett, 2002: 34). This is exactly what Coudreau's books allow. Being constructed like diaries relating his dialogues and daily relations with Indians, the explorer's command of a good number of the region's indigenous languages allowed Coudreau to convey an understanding of the Other through empathy. Other explorers, however, tended to depict Amerindians through the very thick lenses of their own ideologies. Schomburgk, for example, who

F. Ferretti, 2017: "Tropicality, the unruly Atlantic and social utopias: the French explorer Henri Coudreau (1859-1899)", Singapore Journal of Tropical Geography 38, 3, early view: http://onlinelibrary.wiley.com/doi/10.1111/sjtg.12209/full 
was very committed to the Christian faith, envisaged absolute evil in what he could understand of the Indians' beliefs, arguing that 'the Indian is professor of Demonology' (Burnett, 2000: 183).

The second figure was the French 'Big Man' of Amazonian exploration, Jules Crevaux (Crevaux, 1847-1882), Coudreau's immediate predecessor. Unlike the latter, Crevaux was a very official and publically acknowledged explorer, decorated with the Legion of Honour and directly connected with the French government. He was also a solid Catholic, committed to evangelization and certainly not empathetic towards indigenous beliefs. According to Francis Grandhomme, Crevaux 'did not seem a lover of humanity: unequal exchanges with the Indians, the sacking of burial grounds, simulated execution of an old Indian charged with theft; he displayed prejudices and racism' (Grandhomme, 2011: 181). ${ }^{1}$ Crevaux wrote openly that, when approaching Indians, i.e. persons placed at the limits of humankind, Europeans 'should present themselves as their masters' (Crevaux, 1987: 94). He was surprised to discover that one of his assistants was able 'to pose intelligent questions, albeit a Negro' (Crevaux, 1989: 377). French literature continues to be laudatory towards Crevaux, as in the case of geographer Emmanuel Lézy who tells of an episode in which a hungry Crevaux fired on the inhabitants of a village to steal their food, and refers to the French explorer as 'the poor man' (Lézy, 2008) without expressing the same compassion for the victims of this predatory assault.

On the other hand, Coudreau is thought of as a minor figure in France, where it seems he is still paying for his insubordination to the government of the Third Republic. With his studies in history and geography behind him, Coudreau accepted an appointment at the French lycée in Cayenne in 1880. His first official expedition on behalf of the French government took place from 1883 to 1885 (Benoit, 2000: 24) and was directed towards the exploration of the area between French Guiana and the Brazilian state of Pará, which was disputed at the time by France and Brazil. The expedition ended with his desertion. Coudreau disobeyed the orders he had received and travelled quite a long distance in the opposite direction, going up the Amazon River in Brazilian territory to reach the border area of Colombia, Venezuela and British Guiana. The more than 1000 pages of his book La France équinoxiale [Equatorial France] (1886-1887) allows us to follow his wanderings almost day by day.

F. Ferretti, 2017: "Tropicality, the unruly Atlantic and social utopias: the French explorer Henri Coudreau (1859-1899)", Singapore Journal of Tropical Geography 38, 3, early view: http://onlinelibrary.wiley.com/doi/10.1111/sjtg.12209/full 
In the next section I will address the specific reasons of Coudreau's unruly behaviour. What is important to underscore now is how, in this two-year journey in Amazonia, Coudreau discovered indigenous peoples and was marked by the encounter for the rest of his life. Coudreau did not travel with big expeditions like Crevaux or Stanley, but with small groups that included in the first years Apatou, a member of the Boni Afro-descendant community who was formerly Crevaux's assistant. Coudreau wrote that in 1884, he 'remained alone for nine months, without Apatou... between the sources of the Rio Branco and the Trombetas [among] authentic savages: none of them was dressed, none spoke any other language than the dialect of his tribe, and none had seen a white man before. From July 1884 to March 1885 I lived, talked and even thought like an Indian. I put myself completely in the skin of a savage' (Coudreau, 1887b: 111). Even if Coudreau never abandoned a Eurocentric terminology and some ethnocentric prejudices, his efforts to deal empathically with other cultures are clear from this first contact. While Coudreau's early writings show that his education included the most dreadful racist statements of the time toward black peoples (Coudreau, 1881), his later approaches to indigenous communities seem very original in comparison to more canonical explorations. First, he did not use 'corrective' violence towards the natives or the expeditions' members (most of them afro-descendants), unlike other explorers and geographers (on the behaviour of Halford Mackinder with the members of his African expeditions, see Kearns, 2009: 111). Coudreau never brought alcohol to Indians for ethical reasons, considering it one of the instruments of their destruction, 'unlike what Crevaux did' (Benoit 2000: 69), nor did he look to spread the gospel, being an atheist. He also derided the missionaries, saying that they were recruited 'among the worst' and viewing their churches as 'schools of depravation' (Coudreau, 1887b: 85).

An important point was Coudreau's willingness to learn Indian languages, allowing him to publish some of the first Indian dictionaries and translations of Amerindian poems. Multilingualism was a feature of Coudreau's method; fluent in Portuguese, English, the creole of Guiana's blacks, and the Amazonian Lingua Geral, the explorer was fascinated by the discovery of Amerindian languages and wrote to his French public, 'You do not know what wonderful treasures of primitive literature these Indian languages contain. They are the charm of the virgin forest, from Cayenne to the Andes and from the Andes to the shores of Brazil' (Coudreau, 1887b: 187).

F. Ferretti, 2017: "Tropicality, the unruly Atlantic and social utopias: the French explorer Henri Coudreau (1859-1899)", Singapore Journal of Tropical Geography 38, 3, early view: http://onlinelibrary.wiley.com/doi/10.1111/sjtg.12209/full 
A number of episodes indicated Coudreau's progressive rejection of the alleged superiority of the civilized during his stays. Once, suddenly sick and abandoned by his small crew, the explorer remained a couple of weeks in a state of unconsciousness and was saved by an old Indian woman who refused to follow her tribe's migration in order to care for him. Coudreau regretted being even unable to give readers her name 'because she did not have one: she was simply called Grandmother' (Coudreau 1887a: 293). And with some self-deprecation, Coudreau points out that he was occasionally derided by the local peoples because the great explorer could not swim. If the figure of the heroic explorer killed by 'bad' natives was a commonplace for the literature of that time (Crevaux indeed died in such circumstances), Coudreau's empathy and linguistic skills allowed him to criticize the violent behaviour of former explorers in Amazonia like the Brazilian Fernando, who harassed the Atorradis Indians in their home region with his 'abuses of power [while] his gang sacked all Indian houses' (Coudreau, 1887a: 272). Coudreau also speaks about cases of rapes and murder by this civilizer, and the fact that Fernando eventually disappeared, probably killed by the Indians, does not seem to affect the French traveller.

Indian society was one of the first of Coudreau's interests; he was clearly fascinated by the absence of power and state authority, which characterized the Amazonian region, where state control was 'an illusion' (Coudreau, 1887a: 224). Some of his references suggest that, before meeting Reclus and starting his correspondence with him, he was already familiar with socialist and anarchist theories (in particular Saint-Simonianism, as I explain in the next section). Coudreau mentions 'the republic according to Kropotkin' (Coudreau, 1886: 395) in a volume published in 1886, when Kropotkin was not yet famous as a theorist. Also, he refers to the concept of 'propaganda by the deed' (Coudreau, 1886: 291), which was rather new in French anarchist milieus of the time (Maitron, 1983). All this suggests that by the 1880s Coudreau had some acquaintance with French anarchists. Coudreau observes that in the tribes of the Guianas and Brazilian Amazonia, 'the chiefs have no authority other than their moral one. This is pure anarchy, realized by a people simple and without needs' (Coudreau, 1887a: 309). According to the French explorer, 'This anarchist condition is established and maintained thanks only to [great sacrifices]. The civilized man works, or makes others work, to satisfy fictitious needs. Who is the happiest? To answer this question would be to revive Rousseau's Discourse on Inequality. Nevertheless, Indians

F. Ferretti, 2017: "Tropicality, the unruly Atlantic and social utopias: the French explorer Henri Coudreau (1859-1899)", Singapore Journal of Tropical Geography 38, 3, early view: http://onlinelibrary.wiley.com/doi/10.1111/sjtg.12209/full 
are happy... freer than every citizen of Europe or North America, without chiefs, without functionaries.... As they have no notion of progress, they do not struggle for progress - what else is there to be happy?' (Coudreau, 1887a: 310).

In his subsequent works, Coudreau confirms his enchantment with Indian fraternity, which he connects with the French Revolution's 'liberty and equality'. 'Happiness and well-being in the forests, happiness and well-being in the village where one and the same family dwells, equality at table, liberty that knows not the tyranny of any law, and all the fraternity compatible with the human heart' (Coudreau, 1893: 226). Indian social equality was opposed to European social hierarchies, which Coudreau condemned. 'One is almost shocked at not meeting the two social castes that from our schooling on we are inculcated to consider as having always existed and having to exist always like a fatal necessity... the caste of those who are born accursed and the caste of those who are born blessed' (Coudreau, 1893: 245). Coudreau even quoted a famous phrase by the anarchist Pierre-Joseph Proudhon, ironically enumerating the many constraints of bourgeois democracies. 'One is embarrassed not to see everybody voting and thinking themselves satisfied. One is shocked not to find those hundreds of thousands of laws, decrees, regulations which in our land command, forbid, restrict, explain, constrain, warn, and punish, making man the material thing of that abstract thing called the state' (Coudreau, 1893: 246). Another characteristic of the 'Indians' anarchism' was their habit of crossing political borders without perceiving them. Coudreau, in the tropical forest, felt himself free and 'a citizen of the world' (Coudreau, 1887a: 368), among people 'without subordination and authority centres, where property does not exist' (Coudreau, 1887a: 397).

As shown by the aforementioned reference to the Discourse of Inequality, the influence of Rousseau's 'noble savage' played a role, and one might wonder on the absence, in Coudreau's writings, of a key figure for authors studying 'radical' or 'anti-imperialist' Enlightenment such as Jonathan Israel or Sankar Muthu, i.e. Denis Diderot (1713-1784), the author of the Supplément au Voyage de Bougainville [Addition to Bougainville's Travel], considered as a manifesto for Enlightenment anti-colonialism and praise for indigenous peoples (Carey \& Festa, 2009; Israel, 2001). According to Muthu, thinkers like Diderot questioned the idea of 'noble savage' by arguing that isolated 'men' and purely 'natural' society do not exist, as every human group exercises some

F. Ferretti, 2017: "Tropicality, the unruly Atlantic and social utopias: the French explorer Henri Coudreau (1859-1899)", Singapore Journal of Tropical Geography 38, 3, early view: http://onlinelibrary.wiley.com/doi/10.1111/sjtg.12209/full 
form of cultural agency (Muthu, 2003). Though Coudreau's statements on the social organization of indigenous tribes recall elements of Diderot, the lack of direct references shows the limits of Coudreau's readings; it is likely that the explorer assumed indirectly elements of Diderot's thinking, accordingly by reading Reclus and Kropotkin. Yet, unlike Diderot and Rousseau, Coudreau focused not on theoretical speculation, but on his empirical experience and one of his originalities lies in his questioning of the very idea of civilization, a supposedly inevitable thing. Fieldwork experiences provided Coudreau with elements of cultural relativism, prompting him to reject positivism, as can be seen in the sarcasm he levels at 'the fanatics of the very debatable doctrine of infinite progress' (Coudreau, 1887a: 365). From a methodological standpoint, it is worth highlighting a number of Coudreau's critiques of what is now called 'essentialism'. Even as a 'man in the field', Coudreau was well aware of the theoretical debates that were playing out and reproached the Swiss scholar Louis Agassiz for 'those premature generalizations which scientists love so much... one thinks one knows the Indians after having observed some dozens of them. But after thirty months of intimate living with them, I am only beginning to be aware of their complexity' (Coudreau, 1887a: 411).

According to Benoit, Coudreau anticipated here some topics of the later anarchist anthropologist Pierre Clastres (1934-1977) who argued in his Society against the State (1974) that some Amazonian peoples whose stateless institutions were seen as a marker of 'backwardness' were, on the contrary, aware of the need to avoid the concentration of power. Even if Coudreau's analyses never achieved the same theoretical density, it is worth noting that there is a tradition in anarchist anthropology that views so-called primitives, and in particular hunter-gatherers, as groups whose study can shed light on the working of a self-governing society. In Coudreau's day, it was the case for Elie Reclus (1827-1904), Elisée's brother and collaborator, and it is now the case for anthropologists like David Graeber, Brian Morris, Harold Barcaly and James Scott, the latter arguing that "not so very long ago, such self-governing peoples were the great majority of humankind' (Scott, 2009: ix). Thus, one can understand Coudreau's disappointment with civilized life, as well as his invitation to Europeans willing to leave a society based on the exploitation of labour to embrace this supposedly primitive environment. 'Once you have completed your education as a savage, you will walk with no fear whatsoever in the Counani forest, knowing that

F. Ferretti, 2017: "Tropicality, the unruly Atlantic and social utopias: the French explorer Henri Coudreau (1859-1899)", Singapore Journal of Tropical Geography 38, 3, early view: http://onlinelibrary.wiley.com/doi/10.1111/sjtg.12209/full 
it has a better sort of people than the [London] City and is safer than the boulevards of Paris' (Coudreau, 1886: 389).

Returning to France in 1886, Coudreau had a certain success with his books but he was then deemed persona non grata by the ministry of colonies. After numerous attempts, he managed to obtain new funding from the ministry of instruction to study the indigenous tribes of the interior of Guiana, but with strict and clear instructions not to travel 'outside the borders of uncontested Guiana' (Benoit, 2000: 115). Of course, this prohibition would not be respected by the explorer, as I explain below. For four years, from 1887 to 1891, Coudreau lived among the indigenous Guianese populations of the interior, and his work on that time with them contains his most vivid defence of the 'savages' and expressions of 'disgust for the injustices and disgraces of civilization' (Coudreau, 1893: 99).

Allergic to borders like 'his' Indians, Coudreau recounts in these terms his nth border violation. 'Here we are in the territory disputed by France and Brazil... Unaware of this detail of political geography, the Oyampis naively imagine that this land, which they have inhabited and cultivated for a century, belongs to them. Not at all, my friends, it is the French (unless it is the Brazilians) who are at home, and soon to reward you for having trustingly opened your country to us, white men, with their firewater and their diseases unknown to you, will make your race disappear down to the last man in the name of the superior principles of civilization and progress. There will be many white men upon the land of the destroyed Oyampis... New cities, that is big stone houses, will rise there. These houses will not belong to their inhabitants, like your malocas [barracks], which are yours; no, they will belong to sorts of very fat tamouchis [Indian chieftains], whom we call landlords. All this land will be a series of fields that have been cleared of their trees, but there will be precious few of these fields that belong to those who work them' (Coudreau, 1893: 332). With private property, Coudreau warned, the state will establish its civil and military apparatus. 'There will be trials, there will be catchpoles, there will be excisemen poking around in cellars. The more one will work, the less one will eat, and the more one will be obliged to give cassava and yams to the great chef... When one would like to go and gather wood in the forest, swim naked in the river, or kill hoccos and agoutis, there will be a soldier to say "Off to prison with you". One will be decked out in magnificent feathers... and when the tamouchis say "Left foot up,

F. Ferretti, 2017: "Tropicality, the unruly Atlantic and social utopias: the French explorer Henri Coudreau (1859-1899)", Singapore Journal of Tropical Geography 38, 3, early view: http://onlinelibrary.wiley.com/doi/10.1111/sjtg.12209/full 
face right" those who disobey will be shot... That is the goal the human spirit must aim for, at least according to our own white piayes [sorcerers]' (Coudreau, 1893: 332).

What is clear is that Coudreau, in these writings on Amazonian Amerindians, came to agree with the scholarship of the anarchist geographers who addressed native peoples, denouncing what Elie Reclus, in his work Les Primitifs [Primitives], called the 'murderous civilization' (Reclus 1885: 142). In his following work, Le Primitif d'Australie [Australian Primitives], the elder of the Recluses cited Coudreau as an example of a European traveller unable to readapt himself to the socalled civilized life. 'Travellers like Coudreau... tell us they never felt as much happiness as in the free life of the savage; they say they returned with unease, even fear, to our fields enclosed with hedgerows, our cities girded by the ditches and walls of taxes and tariffs, our narrow, suffocating streets' (Reclus, 1895: 75).

\section{'Free Amazonia': Coudreau's tropical utopia}

When he went back to Europe, Coudreau contributed to the political debates about French politics in Guiana and his position was an individualistic and unorthodox one. South America at that time was a secondary issue for French foreign politics, which were more focused on colonial endeavours in Africa. Coudreau's frequent demands for a more progressive role for the French in South America provoked some misunderstanding by French writers addressing his work, like Benoit, who defined Coudreau as a 'national hussar' (Benoit, 2000: 105). This interpretation is unable to make sense of the originality of the explorer. A careful reading of Coudreau's works on the Amazonian question and the border dispute between France and Brazil shows that he never requested governmental, military or diplomatic intervention in this area. I argue that it was simply because he was uninterested in 'reason of state', and his utopian projects drew on free migration and spontaneous miscegenation outside of any institutional framework. The fact that Coudreau was an 'atypical explorer', far from the 'exacerbated nationalism' of his colleagues, has not escaped the notice of recent Brazilian scholarship, namely the dissertation by Durval de Souza Filho (Souza Filho, 2008: 31).

In his work Les Français en Amazonie, as well as in several papers, Coudreau expresses his idea of the Counani (the present-day Brazilian region of Amapa, the core of the disputed

F. Ferretti, 2017: "Tropicality, the unruly Atlantic and social utopias: the French explorer Henri Coudreau (1859-1899)", Singapore Journal of Tropical Geography 38, 3, early view: http://onlinelibrary.wiley.com/doi/10.1111/sjtg.12209/full 
territory at the time) as a part of the wider Amazonian region, which he saw as a 'distinct geographical realm' (Coudreau, 1887b: 20) from a hydrographical, naturalistic and cultural standpoint. He was not interested in deciding whether this area should belong to France or Brazil, but in the creation of a new and more equalitarian society through workers' migration and marrying with local populations. While this set of ideas was not foreign to some justifications of colonialism, it is worth noting that Coudreau was never helpful to French expansion in the region; on the contrary he was considered a maverick and an unwelcome troublemaker.

It is in the context of Coudreau's idea of a society independent of the state that we need to read some of his paradoxical statements to the French public, such as 'We will have Amazonia without conquest or diplomacy' (Coudreau, 1887b: 5), to which he added provocatively that French culture was more widespread in Manaus and Pará 'than in [the formal French colony of] Cayenne' (Coudreau, 1887b: 10), and that it was not a problem if the new republic 'speaks Portuguese instead' (Coudreau, 1887b: 20). These declarations were likewise problematic for Brazil because Coudreau's claims for a free republic recalled the existence of a separatist republican movement in Manaus working to secede from the Brazilian empire (between 1888 and 1889 Brazil became a federal republic and slavery was abolished): 'These senhores already have their flag, their program and their constitution' (Coudreau, 1887b: 5). This explains Coudreau's insubordination during his mission of 1883-1885. For his projects, he needed to visit Manaus, a city that was then experiencing an economic boom due to the commercialization of rubber; the influx of workers from Brazil and abroad had remade Amazonia into a 'new and very progressive region' (Coudreau, 1887b: 17). Coudreau's projects drew first on social reform. The explorer raged at the exploitation of Indians and migrants in the seringas of rubber production, which he attributed mainly to 'shameless traders' (Coudreau, 1887a: 55), proposing that free immigration replace slavery and serfdom, to 'avoid the dispossession of modest colonists' (Coudreau, 1887b: 45). The Amazonian society would have been balanced by encouraging the migration of families rather than single males in order to avoid alcoholism and rape, and to target breeding between the local peoples and immigrants in the long term. This would have implied 'the solution of the social question' (Coudreau, 1887a: xiii) and the recovering of 'the millions of wretches whom industrial competition has plunged into the most dreadful situations' (Coudreau, 1887b: 65).

F. Ferretti, 2017: "Tropicality, the unruly Atlantic and social utopias: the French explorer Henri Coudreau (1859-1899)", Singapore Journal of Tropical Geography 38, 3, early view: http://onlinelibrary.wiley.com/doi/10.1111/sjtg.12209/full 
While these ideas were not an absolute novelty for European social thinking in colonial periods, Coudreau's originality led first to his denunciations of civilization's misfits and his statements about the necessity of avoiding 'the criminal ineptitude' (Coudreau, 1887b: 66) of the French administration in Guiana. Second, the partners in Coudreau's projects were the Indians, given that Europeans, due to the tropical environment, "will not be able to settle or make their way into this land without crossbreeding with the indigenous people' (Coudreau, 1887b: 165). This clashed with the development of scientific racism, which in the same decades was inspiring ideas about 'racial purity' that abhorred miscegenation (Coquery-Vidrovitch, 2003). It is worth noting that Coudreau, in this period (the mid-1880s), was still steeped in European prejudices, which can be seen in his confused use of expressions like 'inferior races' (Coudreau, 1887b: 53). But in his utopia of a free Amazonia, what stands out in the end is that it had to be realized as a spontaneous social movement and not by state intermediation. 'I want neither bureaucrat nor law' (Coudreau, 1887b: 178).

An example of Coudreau's exploration methods, and his insubordination with respect to the French government, is his repeated border violations in British Guiana during the expedition of 1883-1885. This further clarifies Coudreau's rejection of borders and his empathy with Indians. 'I was facing the English border... but where is the border? It follows little streams or imperceptible reliefs, or better, it simply does not exist, because here there is a huge area disputed by Brazil, England and Venezuela. But whatever the line chosen in the end, it will always be an open frontier' (Coudreau, 1887a: 271). Coudreau derided colonial cartographers like Schomburgk, arguing that in such disputes 'all the American maps show borders favourable to Americans, all the European ones show borders favourable to Europeans... But one day, there will no longer be any need of petty disputes over mediocre strips of territory. When Europe collapses, America, its heir, will apply the Monroe doctrine integrally' (Coudreau, 1887a: 412). This suggests that Coudreau was already sympathetic in his first voyage to the decolonized South American republics, as he later shows by accepting a Brazilian appointment. In any case, Coudreau's exploration methods seem consistent with his program, which was detached from the logic of government and colonialism. From a technical standpoint, Coudreau's method was what Graham Burnett defined as the 'traverse survey' as opposed to the 'trigonometric survey' (Burnett, 2000: 10), which must be done by big

F. Ferretti, 2017: "Tropicality, the unruly Atlantic and social utopias: the French explorer Henri Coudreau (1859-1899)", Singapore Journal of Tropical Geography 38, 3, early view: http://onlinelibrary.wiley.com/doi/10.1111/sjtg.12209/full 
well-equipped survey groups. So Coudreau was not really interested in 'accurate' surveys because he first explored the cultures and societies he met; his main quantification efforts were very rough estimations of the hypothetical agricultural resources of the regions. We do not find in Coudreau the 'objectivation of the gaze' (Burnett 2000: 11), or the 'anxiety for landmarks' (Burnett, 2000: 16), which characterized Western science and explorations at that time. On the contrary, Coudreau gave voice to much subjectivity, irrationality too, that is, in his narratives, experiences including hunger and gastronomic satisfaction, bodily suffering and sexual desires accompany the explorer's feelings towards the landscapes and the peoples he meets. Thanks to his Saint-Simonian inspiration, Coudreau broke away from the 'performativity of the myth of El Dorado' (Burnett, 2000: 26), which moved other explorers like Schomburgk, since Coudreau often repeated that gold rushes had an antisocial function and that the 'true wealth' (Coudreau, 1887b: 71) of Amazonia, deserving of workers' migrations, lay in its agricultural resources and their daily work rather than in easy gains by mining.

It should be pointed out that Coudreau was always despised by French (colonial) adherents to the 'exact' survey and 'accurate' mapping. This was the case with Jean Hurault who, in 1973, after the first 'scientific' survey of Guiana, anachronistically decried the inaccuracy of some travel distances given by Coudreau. Although the latter had only his feet to do such estimations, Hurault argued for 'erasing all Coudreau's impostures' (Hurault, 1973: 250), accusing the explorer of making maps 'without method and without supervision' (Hurault, 1973: 244). What should give us pause is that this adherent of positivist cartographic reasoning criticized Coudreau for having trusted in vernacular sources whereas, according to Hurault, 'anyone who knows the Indians of Guiana is aware that they have plenty of fantasy and no critical spirit' (Hurault, 1973: 249). While similar essentialist and racist statements were common in French tropical geography even into the 1970s, it is possible to appreciate the originality of Coudreau's method, which is devoid of both a great deal of the positivist thinking of his time and the objective view from nowhere, which characterized mainstream geographical explorations (Pratt, 1992).

\section{Unruly Coudreau: between Counani and Brazil}

F. Ferretti, 2017: "Tropicality, the unruly Atlantic and social utopias: the French explorer Henri Coudreau (1859-1899)", Singapore Journal of Tropical Geography 38, 3, early view: http://onlinelibrary.wiley.com/doi/10.1111/sjtg.12209/full 
As I argued, in the aforementioned Franco-Brazilian border dispute Coudreau's behavior was not functional to French imperialism, and that on the contrary, his work had objective outcomes that ran counter to French (and European) colonial interests. In his early writings on the disputed territory, Coudreau stated that it should be 'an allied country and not a protectorate' (Coudreau, 1887a: xii-xiii). Coudreau's main point about the border dispute was that there was no need to annex this land, because it was already settled by French nationals, who shared it "with a friendly nation, Brazil' (Coudreau, 1885: 4), signifying that he was not interested in formal state sovereignty, but in the real composition of local society. Coudreau describes the stateless communities that lived in the territory and proudly speaks of his friendship with one of the local leaders, Trajano Benito (Coudreau, 1887a: 18), a former Brazilian slave whom Romani sees as an exemplary exponent of the local mixed, stateless and seminomadic populations dwelling in the Disputed Territory, part of a multicultural 'Caribbean circulation'. According to Romani, 'Trajano was neither French nor Brazilian, nor from anywhere; did no homeland generate him. It is nonsense of the official history to claim the loyalty of someone whom his homeland never wanted to be free' (Romani, 2013: 88). Coudreau defined these multiethnic communities as 'autonomous, independent, in anarchy' (Coudreau, 1887a: 5) and the authority of local leaders always subject to collective approbation. Coudreau observed that in local assemblies the principle of majority was not applied, as no corrective power existed for compelling a dissenter to obey, thus there existed the 'inviolability of the right of minorities' (Coudreau, 1887a: xxxv), another classic theme of anarchism. Coudreau calculated that the contested territory was settled by almost 60000 people, mainly 'Indians, maroons [blacks who had escaped slavery in Brazil], and some prisoners escaped from Cayenne' (Coudreau, 1887a: 57), people who 'live today in a state of anarchy, outside both French and Brazilian influence' (Coudreau, 1887a: 59) and in a peaceful way because 'liberty has moralized them' (Coudreau, 1887a: 59)

In the 1890s, the situation degenerated into armed conflicts involving French troops, and thus France and Brazil decided to resolve the dispute through the arbitration of the Swiss government (Ferretti, 2015). Coudreau was completely unfamiliar with diplomatic affairs and mocked the absurdity of establishing the right of one nation on the basis of an ancient diplomatic agreement. The official task of the Swiss arbitrators was to establish which river was the 'Oyapock'

F. Ferretti, 2017: "Tropicality, the unruly Atlantic and social utopias: the French explorer Henri Coudreau (1859-1899)", Singapore Journal of Tropical Geography 38, 3, early view: http://onlinelibrary.wiley.com/doi/10.1111/sjtg.12209/full 
that Vicente Pinzon reached in 1500 and the Treaty of Utrecht of 1713 established as the legitimate border between the French Empire and the Portuguese one, which eventually gave rise to Brazil. At the time, however, nobody could exactly locate this river on a map; thus, according to Coudreau, 'that treaty, instead of ending the conflict... rendered it diplomatically insoluble for the future' (Coudreau, 1887a: 133). Here Coudreau agrees with Elisée Reclus's position on the same problem. The anarchist geographer argued the point in these terms, 'Which is this river Yapok or Vicente Pinzon that the Utrecht diplomats, unfamiliar with American things, wanted to mark on their rudimentary maps? ... One could fill libraries with the reports and diplomatic documents published on this insoluble question' (Reclus, 1894: 86). An ironic outcome of these debates was the use by the Swiss arbitrators of works by both Reclus and Coudreau, French geographers uninterested in claiming new colonial territories for France, to justify their decision to attribute all the disputed territory to Brazil. Their position differed radically from that of the nationalist French geographers whose work helped in drafting the French memoranda in the dispute, men like Vidal de la Blache. An unpublished map by Coudreau conserved in the Reclus cartographical archive in Geneva was even used by the Swiss government (Ferretti, 2015).

By the time the Swiss decision was made public (December 1900), Coudreau had already died of malaria during his last expedition on the Trombetas River in November 1899. What is most important to understand then is his attitude towards the possible uses of the contested territory. Coudreau's name is often linked to the short-lived experience of the 1886-1887 Republic of Counani (Benoit, 2000: 114-115), a self-proclaimed independent republic run by Jules Gros, a member of the Paris geographical society. The attempt was unanimously derided by later commenters, starting with Reclus. 'All of Paris laughed at an honourable Vanves geographer [Gros] who suddenly became the head of a state whose name was unknown; he surrounded himself with a court, established his ministry, and founded a national order, the Etoile Counani, with more commandants, grand-cross officers and knights than inhabitants in the capital' (Reclus, 1894: 85). It is worth noting that Coudreau had no part in this undertaking because he had left the disputed territory in the summer of 1886 (Coudreau, 1886) before the new state was proclaimed; thus, his claims for the establishment of a free territory in Counani were indeed written before this

F. Ferretti, 2017: "Tropicality, the unruly Atlantic and social utopias: the French explorer Henri Coudreau (1859-1899)", Singapore Journal of Tropical Geography 38, 3, early view: http://onlinelibrary.wiley.com/doi/10.1111/sjtg.12209/full 
experience (Puyo, 2012), and Coudreau can be possibly seen as one of the inspirations of the Counani Republic, not one of its protagonists.

Coudreau's ideas on an independent Counani referred to an ideal situation and contradicted the work of French and Brazilian diplomacy involving the territory. 'Would they deny you the right to exist only because 173 years ago diplomats who knew nothing about geography signed a nonsensical treaty? You will be, tell them, neither French nor Brazilian, that is your right. Hurrah for Counani! America for Americans' (Coudreau 1886: 415-416). Settled by a mixed population, this stateless territory was the ideal scenario for locating Coudreau's tropical utopia. 'Sound the death of ancient civilization, the ruin of ancient societies based on hierarchy and pauperism and, as in the vision of a Jewish prophet, sound the final verse of the song of humanity. Topple the broken institutions upon the burning palaces, politics upon science, and science upon the pipe dream of progress' (Coudreau, 1886: 398). At a time when scientific positivism was a dominant ideology, a European geographer speaking against progress is surely worth considering as an original figure. 'Would you like to live without the regret for yesterday and the fear for the morrow, in the certainty of a happy future, blessed by nature, without a newspaper or a deputy, far from all the idiocies and all the villainies of our weary and sick civilization... with only a few families of naked Indians? Then you will love Counani' (Coudreau 1886: 388). On the other hand, this utopia clearly stands in the field of socialism, with some anarchist touches. 'New people will resolve the problem of societies without government here, when the ancient and sick political aggregations are transformed in this Eden' (Coudreau 1886: 390-391). About Counani's government, Coudeau writes, 'It is not yet the Republic after Kropotkin's own heart. Yet Counanians can justify their government saying that it governs nothing at all... It has one curious particularity, namely that it is not harmful to the governed because it does not exist' (Coudreau, 1886: 395). Thus, the ideal government is its total absence. 'I think one day this land of Counani will be one of the schools for the application of the socialism of the future. Likely to witness the acclimation of all human races, it will make it possible to resolve the difficult equation of the races' (Coudreau, 1886: 396). Not only was the idea of miscegenation reiterated in Coudreau's 'advertising' for migration to the New World, but he also gets into a bit of anti-governmental sarcasm, 'Fowl? It is a plague upon the

F. Ferretti, 2017: "Tropicality, the unruly Atlantic and social utopias: the French explorer Henri Coudreau (1859-1899)", Singapore Journal of Tropical Geography 38, 3, early view: http://onlinelibrary.wiley.com/doi/10.1111/sjtg.12209/full 
country and the birds, by your leave, make as much noise as our honourable Deputies Chamber in times of ministerial crisis' (Coudreau, 1886: 412).

In 1895, marginalized and deemed a dangerous person by the French government, Coudreau accepted a post offered by the governor of the Brazilian state of Pará, Lauro Sodré. Durval de Souza Filho observes that Coudreau's tropical utopias were not a far cry from Brazil's national founding myths (Souza Filho, 2008: 29). Moreover, Coudreau's idea of tropicality, his multilingualism and his direct implication with local politicians prefigure some aspects of what Gilberto Freyre called 'Lusotropicalism'. According to Eric Morier-Genoud and Michel Cahen, contemporary myths on Lusophony take their inspiration from 'the formation of autonomous social spaces of migration' (Morier-Genoud \& Cahen, 2012: 1) which occurred not within the Portuguese empire, but between Portugal and its former Brazilian colony, including especially European workers. Drawing on Morier-Genoud's and Cahen's question, 'were the diasporas in favour or against empire, in favour of or against decolonization?' (Morier-Genoud \& Cahen 2012: 13), it is possible to argue that the case of Coudreau shows all the problematic nature and ambiguity of migrations in imperial contexts.

At that time, the model of the decolonized Latin American republics interested European anarchists and anti-colonialists like Reclus, who visited Brazil in 1893 and endorsed the transformation of an ancient empire practising slavery into a federal and abolitionist republic (Carris Cardoso, 2006). In Brazil Reclus was praised both by the nascent workers' movement and by the new liberal bourgeoisie. In 1903 Brazil found itself with a new frontier dispute, this time with British Guiana. The diplomat Graça Aranha contacted Reclus for maps that would assist Brazil in the new dispute. According to Aranha's memoirs, Reclus accepted the diplomat's request to counter the interests of the British Empire (Castro Azevedo, 2002: 75-77). There was then a certain anticolonial concern in Coudreau's change of allegiance in the contest of geopolitical tensions between France and Brazil. Looked upon as a traitor by the French, Coudreau wrote to Reclus in 1896, recalling the Paris Commune: 'The whole of the opportunistic press has accused me of the darkest infamies: lack of patriotism, no aptitude for engaging in bribes... I am now in the same mood as you in 1871 in the inner courtyard of the prison in Versailles, where pretty young ladies

F. Ferretti, 2017: "Tropicality, the unruly Atlantic and social utopias: the French explorer Henri Coudreau (1859-1899)", Singapore Journal of Tropical Geography 38, 3, early view: http://onlinelibrary.wiley.com/doi/10.1111/sjtg.12209/full 
shook with the end of their parasols the bodies of [Communards] who seemed dead, to see the look in the eyes of an irregular shot down' ${ }^{2}$

The collaboration between Coudreau and Reclus in the 1890s was significant. They had met during Coudreau's stay in Paris in 1892-1893, when they were both awarded the 1892 Golden Medal by the Paris Geographical Society. ${ }^{3}$ Coudreau was one of the most important informants and correctors of the nineteenth volume of Reclus's New Universal Geography, in which the anarchist geographer calls Coudreau his 'friend' (Reclus, 1894: 797). From 1895 to 1899, Coudreau worked for the governor of Pará, carrying out seven expeditions along the tributaries of the Amazon and publishing eight books and one atlas. Some of those books were illustrated with the assistance of the Brussels Institute of Geography, which was directed by Reclus at the time and where the handwritten maps sent by Coudreau from Brazil were engraved and sized for inclusion in the volumes. These were published in Paris by Lahure and reviewed by the Brussels anarchist journal Humanité Nouvelle. ${ }^{4}$ In Henri Coudreau's final trips, the explorer was accompanied by his wife, Octavie Renard-Coudreau (1867-1938). Even though Souza de Filho defines them as 'an anarchist couple' (Souza Filho, 2008: 12), Octavie seemed to be politically more conservative than her husband, in spite of her declared friendship to Reclus (Coudreau \& Coudreau, 1899) and the unpublished correspondences in which the anarchist geographer declares his interest in Octavie's travels in Amazonia after Henri's death and his willingness to help her publishing new books with Lahure. ${ }^{5}$ Unluckily, surviving archive material on the Reclus-Coudreau direct relations is not abundant. It is however, worth considering that Coudreau's biography by Max Mouchet, based on the oral recollections Coudreau's younger brother and brother-in-law furnished 'between 1942 and 1944' (Mouchet, 1973: 1), presents the explorer as an anarchist (while he always refused a specific political label) and stresses his proximity with Reclus, meaning that this fact remained in the memory of Coudreau's family. Anyway, it is certain that Reclus and Coudreau were acquainted between 1892 and 1893, when they were both based in the Paris region and worked together for the nineteenth volume of the New Universal Geography on Brazil and Guiana.

Coudreau's books on his Brazilian explorations are one with his socialist concerns, for instance in his denunciations of predatory colonization. Speaking of an Indian tribe known only by name but never encountered because they hid in the forest, Coudreau asks, 'From whom are they

F. Ferretti, 2017: "Tropicality, the unruly Atlantic and social utopias: the French explorer Henri Coudreau (1859-1899)", Singapore Journal of Tropical Geography 38, 3, early view: http://onlinelibrary.wiley.com/doi/10.1111/sjtg.12209/full 
fleeing? Why? They are fleeing civilization, which showed itself to them solely in its mercantile form. And what about the mercantilism exercised between the strongest and the weakest which knows no limit?' (Coudreau 1897: 75). Coudreau also reiterates his love for Indian communities and, feeling even more dejected following his disappointment with his compatriots, argues that 'our destiny is to be always on the run; once we were fleeing hostile tribes, now we are fleeing the civilized, our dear protectors' (Coudreau 1897: 81).

\section{Conclusion}

Henri Coudreau was certainly a very complex and contradictory figure who fits no one classification; although a far cry from the classical model of the European conqueror-explorer, he never achieved a full anti-colonialist and anti-Eurocentric discourse as did anarchist geographers like Reclus (Ferretti, 2013). Nevertheless, his exposure to this critical thinking through his collaboration with Reclus and experience of living with Indian tribes progressively led him to shed a great part of his initial Eurocentric and racist prejudices, and inspired his explicit questioning of the concept of civilization. One can certainly view Coudreau as an example of the complexity and the richness of unorthodox voices within European scholarship in imperial ages and the exponent of an original approach, very far from later French tropical geography, which contemporary authors consider as 'situated in a long history of French colonial incursion' (Bowd \& Clayton 2005: 275). Moreover, Felix Driver has shown that tropicality is a plural and contested concept as the tropical word, more than being the mere scene for a western projection, exercised an agency on its explorers' ideas, first under the form of a 'disturbance' (Driver, 2004: 14). This was clearly the case of Coudreau, which allows us to consider the necessity of empirical studies on the imperial ages' actors in order to overtake the limitations of pure theory and related totalizing narratives.

We can also see Coudreau as part of the history of the rebel Atlantic and specifically the phenomenon that Romani defines as 'a deep cultural circulation which allows us to speak of an Amazonian-Caribbean connexion' (Romani, 2013: 150). Coudreau's tropical utopia of an independent Amazonia based on breeding between the 'races', although described in ambiguous terms, was clearly a socialist one; his invitation to the exploited to come to the tropics to create a new society anticipated some features of tropicality seen as a transformative space, as in the years

F. Ferretti, 2017: "Tropicality, the unruly Atlantic and social utopias: the French explorer Henri Coudreau (1859-1899)", Singapore Journal of Tropical Geography 38, 3, early view: http://onlinelibrary.wiley.com/doi/10.1111/sjtg.12209/full 
1950-60 when the topics were seen as 'militant, as combative, belligerant and seditious — and as seductive' (Clayton, 2013: 180). Coudreau's multilingualism and statements on migration and miscegenation can be understood in the context of the concepts of cosmopolitanism, hybridity and mixed identities that were to later inspire the field of postcolonial cultural studies (Du Gay \& Hall, 1996). As I argued in the introduction, Coudreau's case fits contemporary scholarships interest for the 'contact zones' and provides an early case in international and planetary indigeneity intended as the idea of taking inspiration from these contacts for thinking different ways of life.

All of Coudreau's work was outside the logics of states and colonial diplomacy, which can also explain why his geography was objectively used against the imperial claims of his country. This example reinforces the idea of the complexity of explorers' practices in the field vis-à-vis their writing and publishing on the mainland. It is certainly deserving of additional research focusing on the diversity of individual behaviours rather than essentializing the role of Western civilization, far from being a consistent and linear field. All the contradictions of a maverick individualist like Coudreau can be synthetized by the possessive contained in his statements like: 'This land only belongs to my Indians' (Coudreau, 1893: 527). This reveals all the ambiguities of 'Radical Enlightenment', but also its potentialities, worthy to be rediscovered by contemporary critical scholarship.

\section{Endnote}

1 All quotes by Brazilian and French sources have been translated by the author.

2 French National Library [BNF], NAF 22914, H. Coudreau to E. Reclus, 18 February 1896, f. 65.

3 Bulletin de la Société Française de Géographie [Bulletin of the French Geographical Society] 14, 1893.

4 L'Humanité Nouvelle [New Humanity] 4, 1899, 267.

5 Neuchâtel Public and University Library [BPUN], MS10/1991, E. Reclus to Ch. Schiffer, 30 April 1903.

\section{References}

Akerman J (ed) (2008) The Imperial Map. Chicago University Press, Chicago.

Blais H (2005) Voyages au grand océan: géographies du Pacifique et colonization (1815-1845). CTHS, Paris.

F. Ferretti, 2017: "Tropicality, the unruly Atlantic and social utopias: the French explorer Henri Coudreau (1859-1899)", Singapore Journal of Tropical Geography 38, 3, early view: http://onlinelibrary.wiley.com/doi/10.1111/sjtg.12209/full 
Blaut J (1993) The Colonizer's Model of the World: Geographical Diffusionism and Eurocentric History. Guilford Press, New York.

Benoit S (2000) Henri Anatole Coudreau (1859-1899), dernier explorateur français en Amazonie [Henri Anatole Coudreau (1859-1899), the last French explorer in Amazonia]. L'Harmattan, Paris.

Bowd G, Clayton D (2005) French tropical geography. Singapore Journal of Tropical Geography $26(3), 271-88$.

Bressey C (2013) Empire, race and the politics of anti-caste. Bloomsbury Academic, London.

Burnett G (2000) Masters of all they surveyed, Exploration, Geography and a British El Dorado. University of Chicago Press, Chicago.

Burnett G (2002) It is impossible to make a step without the Indians: nineteenth-century geographical exploration and the Amerindians of British Guiana. Ethnohistory 49 (1), 3-40.

Carey D, Festa L (2009) The Postcolonial Enlightenment: Eighteenth-Century Colonialism and Postcolonial Theory. Oxford University Press, Oxford.

Carris Cardoso L (2006) A visita de Élisée Reclus à sociedade de Geografia do Rio de Janeiro [Élisée Reclus's visit to the Geographical Society of Rio de Janeiro], Revista da Sociedade Brasileira de Geografia 1. Available at:

http://www.socbrasileiradegeografia.com.br/revista_sbg/luciene\%20p \%20c\%20cardoso.html (accessed 25 April 2016).

Castro Azevedo MH (2002) Um senhor modernista: biografia de Graça Aranha [A modernist gentleman: biography of Graça Aranha]. ABL, Rio de Janeiro.

Chakrabarty D (2000) Provincializing Europe, Postcolonial Thought and Historical Difference. Princeton University Press, Princeton-Oxford.

Clayton D (2011) Subaltern space. In Agnew J, Livingstone D (eds) The SAGE Handbook of Geographical Knowledge, 246-61. SAGE London.

Clayton D (2013), Militant tropicality: war, revolution and the reconfiguration of 'the tropics' c.1940-c.1975, Transactions of the Institute of British Geographers 38, 180-92.

F. Ferretti, 2017: "Tropicality, the unruly Atlantic and social utopias: the French explorer Henri Coudreau (1859-1899)", Singapore Journal of Tropical Geography 38, 3, early view: http://onlinelibrary.wiley.com/doi/10.1111/sjtg.12209/full 
Coquery-Vidrovitch C (2003) Le postulat de la supériorité blanche et de l'infériorité noire. [The postulate of White superiority and Black inferiority] In Ferro M (ed) Le livre noir du colonialisme, 646-91. Laffont, Paris.

Coudreau H (1881) Le pays de Wargla [The Wargla country]. Viat, Paris.

Coudreau H (1885) Le territoire contesté entre la France et le Brésil [The territory disputed by France and Brazil]. Danel, Lille.

Coudreau H (1886) La France équinoxiale, vol. I [Equatorial France, vol. I]. Challemel, Paris.

Coudreau H (1887a) La France équinoxiale, vol. II [Equatorial France, vol. I]. Challemel, Paris.

Coudreau H (1887b) Les Français en Amazonie [The French in Amazonia]. Picard, Paris.

Coudreau H (1893) Chez nos Indiens [Visiting our Indians]. Paris, Hachette.

Coudreau H (1897) Voyage au Xingu [Travel to the Xingu River]. Lahure, Paris.

Coudreau H, Coudreau O (1899), Voyage au Trombetas [Travel to the Trombetas River]. Lahure, Paris.

Crevaux J (1987) Le mendiant de l'Eldorado [Begging for Eldorado]. Phébus, Paris

Crevaux J (1989) En radeau sur l'Orénoque [Rafting on the Orinoco]. Phébus, Paris

Driver F, Yeoh B (2000) Constructing the tropics: introduction. Singapore Journal of Tropical Geography 21 (1), 1-5.

Driver F (2001) Geography Militant: Cultures of Exploration and Empire. Blackwell, Oxford.

Driver F, Martins L (eds) (2005) Tropical Visions in an Age of Empire. The University of Chicago

Press, Chicago and London.

Driver F (2004) Imagining the tropics: views and visions of the tropical world. Singapore Journal of Tropical Geography 25 (1), 1-17.

Du Gay P, Hall S (1996) Questions of Cultural Identity. Sage, London.

Featherstone D (2008) Resistance, Space and Political Identities: the Making of Counter-Global Networks. Wiley-Blackwell, Malden-Oxford.

Featherstone D (2012) Solidarity: Hidden Histories and Geographies of Internationalism. Zed, London.

Ferretti F (2013) They have the right to throw us out: Élisée Reclus' Universal Geography. Antipode, a Radical Journal of Geography 45, 1337-55.

F. Ferretti, 2017: "Tropicality, the unruly Atlantic and social utopias: the French explorer Henri Coudreau (1859-1899)", Singapore Journal of Tropical Geography 38, 3, early view: http://onlinelibrary.wiley.com/doi/10.1111/sjtg.12209/full 
Ferretti F (2015) A new map of the Franco-Brazilian border dispute (1900). Imago Mundi, the International Journal for the History of Cartography 67 (2), 229-42.

Grandhomme F (2011) Reconsidérer la figure de l'explorateur du XIXe siècle: le cas de Jules Crevaux (1847-1882) et de l'Amérique du Sud [Reconsidering the explorer's figure in the nineteenth century: the case of Jules Crevaux (1847-1882)]. Outre-mers 98, 179-94.

Harley B (2001) The New Nature of Maps. The Johns Hopkins University Press, Baltimore.

Hurault J (1973) Une chaîne de montagnes imaginaire: les Tumuc-Humac [An imaginary mountain chain: the Tumuc-Humac]. Revue française d'histoire d'outre-mer 219, 242-50.

Ince A \& Barrera de la Torre G (2016) For Post-Statist Geographies. Political Geography 55 (1), $10-19$.

Israel J (2001) Radical Enlightenment: Philosophy and the Making of Modernity, 1650-1750. Oxford University Press, Oxford.

Jazeel T (2014) Subaltern geographies: geographical knowledge and postcolonial strategy. Singapore Journal of Tropical Geography 35, 88-103.

Kearns G (2009) Geopolitics and Empire, the Legacy of Halford Mackinder. Oxford University Press, Oxford/New York.

Keighren I, Withers C, Bell B (2015) Travels into Print: Exploration, Writing, and Publishing with John Murray, 1773-1859. The University of Chicago Press, Chicago-London.

Kennedy D (2014) Introduction: reinterpreting exploration. In Kennedy D (ed) Reinterpreting Exploration, the West in the World, 1-20. Oxford University Press, Oxford.

Lézy E (2008) Jules Crevaux, l'explorateur aux pieds nus. EchoGéo 7. Available at: http://echogeo.revues.org/9983 (accessed 18 March 2017).

Liebersohn H (2014) A half-century of shifting narrative perspectives on encounters. In Kennedy D (2014) Reinterpreting Exploration, the West in the World, 38-53. Oxford University Press, Oxford.

Linebaugh P, Rediker M (2000) The Many-Headed hydra: Sailors, Slaves, Commoners, and the Hidden History of the Revolutionary Atlantic. Beacon Press, Boston.

Maitron J (1983). Le mouvement anarchiste en France [The anarchist movement in France]. Maspero, Paris.

F. Ferretti, 2017: "Tropicality, the unruly Atlantic and social utopias: the French explorer Henri Coudreau (1859-1899)", Singapore Journal of Tropical Geography 38, 3, early view: http://onlinelibrary.wiley.com/doi/10.1111/sjtg.12209/full 
Mouchet M (1973) L'Explorateur Coudreau ou la Philosophie des voyages [The explorer Coudreau. On travel philosophy]. Imprimerie Tschumi-Taupin, Melun.

Morier-Genoud E, Cahen M (2012) Portugal, empire and migration, was there ever an autonomous social imperial space? In Mourier-Genoud E, Cahen M (eds) Imperial Migrations. Colonial Communities and Diaspora in the Portuguese World, 1-30. Palgrave Macmillan, London.

Muthu S (2003) Enlightenment Against Empire. Princeton University Press, Princeton.

Nash C (2002) Postcolonial cultural geographies. Progress in Human Geography 26 (2), 219-30.

Ogborn M (2007) Indian Ink: Script and Print in the Making of the English East India Company.

The University of Chicago Press, Chicago-London.

Pratt ML (1992). Imperial Eyes: Travel Writing and Transculturation. Routledge, London.

Power M, Sidaway J (2004) The degeneration of tropical geography. Annals of the Association of American Geographers 94, 585-601.

Puyo JY (2001) Sur le mythe colonial de l'inépuisabilité des ressources forestières (Afrique occidentale française / Afrique équatoriale française, 1900-1940) [On the colonial myth of limitless forest resources. Western French Africa/Equatorial French Africa, 1900-1940]. Cahiers de géographie du Québec 45 (126), 479-96.

Puyo JY (2012) Du contesté franco-brésilien à la République de Counani: histoire édifiante et curieuse d'une cryptarchie éphémère [From the French-Brazilian border dispute to the Counani Republic: strange and edifying story of an ephemeral cryptarchy]. In Dornel L, Guicharnaud-tollis M, Parsons M, Puyo JY (eds). Ils ont fait les Amériques, 279- 291. Presses Universitaires de Bordeaux, Bordeaux.

Reclus E[lie] (1885) Les Primitifs [Primitives]. Chamerot, Paris.

Reclus E[lie] (1895) Le Primitif d'Australie [Australian Primitives]. Dentu, Paris.

Reclus E[lisée] (1894) Nouvelle Géographie Universelle, Vol. XIX [New Universal Geography, vol. XIX]. Hachette, Paris.

Robinson MF (2014) Science and exploration. In Kennedy D (ed) Reinterpreting Exploration, the West in the World, 21-37. Oxford University Press, Oxford.

F. Ferretti, 2017: "Tropicality, the unruly Atlantic and social utopias: the French explorer Henri Coudreau (1859-1899)", Singapore Journal of Tropical Geography 38, 3, early view: http://onlinelibrary.wiley.com/doi/10.1111/sjtg.12209/full 
Romani C (2013) Aqui começa o Brasil, história das gentes e dos poderes na fronteira do Oiapoque [Here begins Brazil. History of people and power on the Oyapock border]. Multifoco, Rio de Janeiro.

Safier N (2014) The tenacious travels of the torrid zone and the global dimensions of geographical knowledge in the eighteenth century. Journal of Early Modern History 18, 141-72.

Scott J (2009). The art of not Being Governed, an Anarchist History of Upland Southeast Asia. Yale University Press, New Haven.

Sidaway J (2000) Postcolonial geographies: an exploratory essay. Progress in Human Geography 24, 591-612.

Sidaway J, Woon CY, Jacobs J (2014) Planetary Postcolonialism. Singapore Journal of Tropical Geography 35, 4-21.

Souza Filho D (2008) Os retratos dos Coudreau: Indios, civilização e miscigenação através das lentes de um casal de visionarios que percorreu a Amazonia em busca do "Bom Selvagem" (PhD Dissertation). [Portraits of the Coudreaus: Indians, civilization and miscegenation through the lenses of a visionary couple which wandered in Amazonia seeking the "Noble Savage"], University of Belem.

Springer S (2012) Anarchism! What geography still ought to be. Antipode 44 (5), 1605-1624.

Staszak JF (2003) Géographies de Gauguin [Gauguin's geographies]. Bréal, Rosny-sous-Bois.

Stern P J (2014), Exploration and Enlightenment. In Kennedy D (ed) Reinterpreting Exploration, the West in the World, 54-79. Oxford University Press, Oxford.

Surun I (2007) Les figures de l'explorateur dans la presse du $19^{\mathrm{e}}$ siècle [The explorers' figures in nineteenth century press]. Le Temps des Médias 8, 57-74.

F. Ferretti, 2017: "Tropicality, the unruly Atlantic and social utopias: the French explorer Henri Coudreau (1859-1899)", Singapore Journal of Tropical Geography 38, 3, early view: http://onlinelibrary.wiley.com/doi/10.1111/sjtg.12209/full 